\title{
A neuropsychological approach to understanding risk-taking for potential gains and losses
}

\author{
Irwin P. Levin ${ }^{1}$, Gui Xue ${ }^{2}$, Joshua A. Weller ${ }^{3}$, Martin Reimann ${ }^{2}$, Marco Lauriola $^{4}$ and Antoine Bechara ${ }^{2,5,6 *}$ \\ ${ }^{1}$ Department of Psychology, University of lowa, lowa City, IA, USA \\ 2 Department of Psychology, University of Southern California, Los Angeles, CA, USA \\ ${ }^{3}$ Decision Research, Eugene, OR, USA \\ ${ }^{4}$ Department of Developmental and Social Processes, University of Rome, Rome, Italy \\ ${ }^{5}$ Department of Psychiatry, McGill University, Montreal, OC, Canada \\ ${ }^{6}$ Clinical Research Division, Douglas Mental Health University Institute, Montreal, QC, Canada
}

Edited by:

Kerstin Preuschoff, University of

Zurich, Switzerland

Reviewed by:

Bruno B. Averbeck, National Institute

of Mental Health, USA

Philippe N. Tobler, University of

Zurich, Switzerland

Anna Van Duijvenvoorde, University of

Amsterdam, Netherlands

\section{*Correspondence:}

Irwin P. Levin, Department of

Psychology, University of lowa, lowa

City, IA 52242, USA.

e-mail:irwin-levin@uiowa.edu;

Antoine Bechara, Department of

Psychology, University of Southern

California, Los Angeles, CA 90089,

USA.

e-mail:bechara@usc.edu
Affective neuroscience has helped guide research and theory development in judgment and decision-making by revealing the role of emotional processes in choice behavior, especially when risk is involved. Evidence is emerging that qualitatively and quantitatively different processes may be involved in risky decision-making for gains and losses. We start by reviewing behavioral work by Kahneman and Tversky (1979) and others, which shows that risk-taking differs for potential gains and potential losses. We then turn to the literature in decision neuroscience to support the gain versus loss distinction. Relying in part on data from a new task that separates risky decision-making for gains and losses, we test a neural model that assigns unique mechanisms for risky decision-making involving potential losses. Included are studies using patients with lesions to brain areas specified as important in the model and studies with healthy individuals whose brains are scanned to reveal activation in these and other areas during risky decision-making. In some cases, there is evidence that gains and losses are processed in different regions of the brain, while in other cases the same region appears to process risk in a different manner for gains and losses. At a more general level, we provide strong support for the notion that decisions involving risk-taking for gains and decisions involving risk-taking for losses represent different psychological processes. At a deeper level, we present mounting evidence that different neural structures play different roles in guiding risky choices in these different domains. Some structures are differentially activated by risky gains and risky losses while others respond uniquely in one domain or the other. Taken together, these studies support a clear functional dissociation between risk-taking for gains and risk-taking for losses, and further dissociation at the neural level.

Keywords: decision neuroscience, risky decision-making, gain/loss domain differences

\section{INTRODUCTION}

The combination of methods from the behavioral decisionmaking literature such as risky decision-making tasks derived from the classic work of Kahneman and Tversky (1979), and methods of neuroscience such as functional magnetic resonance imaging (fMRI) and lesion studies has led to breakthroughs in both fields. Examples include how impairment in specific brain functions translate into disadvantageous decision-making inside and outside of the laboratory (Bechara et al., 1994, 1996, 1997, 1999) and how common decision-making biases and heuristics can be understood at the neural level (Sanfey et al., 2003; Hsu et al., 2005; Kuhnen and Knutson, 2005; De Martino et al., 2006; Huettel et al., 2006; Tom et al., 2007). New areas of study have emerged with titles such as neuroeconomics and decision neuroscience.

A major contribution of this work has been a better understanding of how emotion, in combination with cognition, guides our decisions, particularly in the realm of risky decision-making where conflicts often arise in balancing the lure of reward and the fear of loss. Evidence is accumulating that emotional reactivity differs in response to risky gains and risky losses. Logical questions are whether risk-taking for gains and risk-taking for losses can best be understood as separate psychological processes, and ultimately, whether they rely on different brain structures. In this paper, we integrate findings from our own work and that of others to come to conclusions that have some generality but also allow for differences between studies based on methodology.

In order to frame this investigation, we start with a model put forth to support the findings from two studies we conducted with patients with lesions to areas of the brain known to be critical to risky decision-making, namely the ventromedial prefrontal cortex (VMPFC), the amygdala, and the insula (Bechara et al., 1999; Clark et al., 2008). As summarized in Figure 1 (from Weller et al., 2007), we propose that risky decision-making is influenced by the opposing forces of lure of gain and fear of 


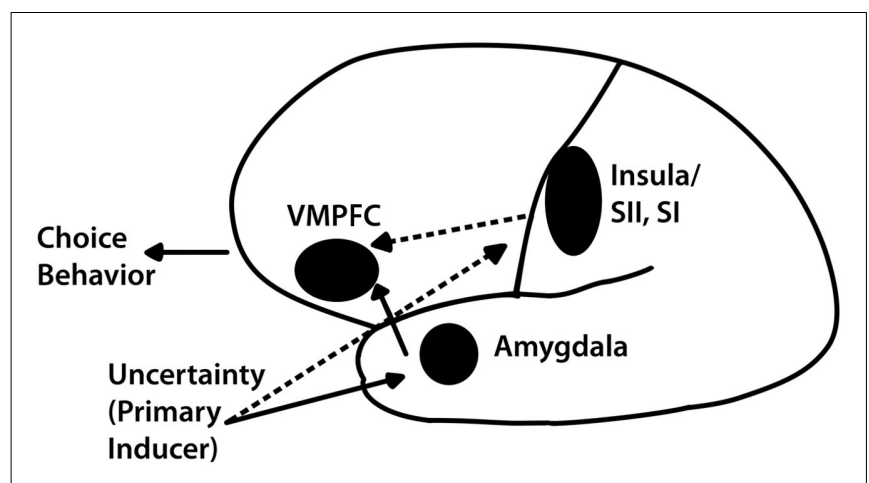

FIGURE 1 | Illustration of the expanded neural model of decision-making under uncertainty. Processing of primary inducers, mediated by the amygdala, triggers the ventromedial prefrontal cortex (VMPFC) system, which, in turn, conducts a more deliberative analysis of uncertainty. However, decisions involving potential losses may trigger redundant neural responding from structures such as the insula (anterior, posterior, or both) and the adjacent primary and secondary somatosensory cortices (SI and SII), which are independent of the amygdala; these backup processes are represented here by dotted lines.

risk $^{1}$. We operationalize the "lure" of rewards as either the potential for a relatively large gain in the gain domain (in comparison to the small sure gain from a riskless choice) or the potential for avoiding a loss altogether in the loss domain, and the "fear" of risk as arising from risking a relatively large loss in the loss domain (in comparison to the small sure loss from a riskless choice) or not winning anything in the gain domain. These two forces act in opposite directions in exciting or inhibiting risk-taking. We suggest that the VMPFC subregions, the amygdala, and the insula each contribute in different ways to the processing and utilization of these two critical pieces of emotional information. The mere presence of uncertainty induces a primary "fear" response elicited by the amygdala, which has been associated specifically with fear processing and avoidance behavior (LeDoux, 2000; Trepel et al., 2005; Phelps, 2006). This fear response activates the VMPFC whose function it is to mediate decision-making and allows for more careful deliberative processes by linking together working memory and emotional systems (Damasio, 1994).

While the amygdala has been studied extensively and shown to be a key substrate for triggering emotional responses, especially in connection with fear (LeDoux, 2000), the fact remains that the triggering of emotional responses involves multiple neural regions, and not just the amygdala. Thus, structures such as the insula, which are independent of the amygdala, are also likely to impact decision-making under uncertainty (Kuhnen and Knutson, 2005; Clark et al., 2008; Weller et al., 2009). In particular, we propose that the insula and the amygdala provide complementary systems for dealing with potential losses, which we attribute to the evolutionary significance of dealing with potential losses. Our ancestors

\footnotetext{
${ }^{1}$ Some definitions of risk include loss as a component. However, in order to incorporate risk-taking for gains and losses, we use a more general definition of risky choice as involving choice options of differing outcome variability. In the typical task described here, the choice is between a "sure thing" or "riskless" option with fixed outcome and a "risky" option with variable possible outcomes.
}

learned to avoid situations that risked the loss of things essential for survival and it is reasonable to assume that our brains have been primed for avoiding losses.

This account parallels the proposed dual systems approach of System 1 (experiential) and System 2 (deliberative) for decision-making (Kahneman, 2003). The neural underpinnings of these mechanisms have also been addressed in the "somatic marker" framework. According to the "somatic marker hypothesis" (Bechara and Damasio, 2005; Reimann and Bechara, 2010), after the amygdala triggers an automatic emotional response (or primary induction), the VMPFC subsequently prompts a more careful deliberative analysis that triggers secondary emotional responses (secondary induction) that help guide advantageous decision-making. Findings in support of the somatic marker hypothesis were key to new behavioral theories in which emotions play a pivotal role in decision-making (Mellers et al., 1999; Loewenstein et al., 2001; Slovic et al., 2002).

In the following sections of this paper, we review the evidence for our model based on studies involving the VMPFC, amygdala, and insula, but we also include studies involving other areas that have implications for addressing the basic question of whether there is evidence at the neural level of a distinction between risky decision-making in the gain and loss domains. We will provide evidence that separate psychological processes are involved in risktaking for gains and losses in terms of both behavioral and neurological reactions that discriminate between risk-taking to achieve a gain and risk-taking to avoid a loss. We then address the more complex issue of whether distinct neural structures support these different reactions. In the case of fMRI studies, we will see that results depend on when during the decision-making process the recordings are made. We start, however, with some more straightforward and well-known behavioral phenomena that motivate the search for neurological dissociations between risk-taking for gains and losses.

It is typical to consider risk-taking as a unified behavioral concept when we talk about a person in terms such as "She is a risk-taker" or "He likes to play it safe." However, it has been shown that risk-taking within the same individual varies across content domains such as monetary, health, and social risks (Weber et al., 2002). Within each of these domains, we may talk about an action as being "risky" because of the uncertainty of its outcome without differentiating between the potential for achieving benefits versus the potential for avoiding aversive consequences. Kahneman and Tversky (1979) demonstrated a fundamental principle that sparked decades of later research: individuals were more likely to take a risk to avoid a loss than to achieve a gain of the same magnitude ${ }^{2}$. Later work by the same authors revealed a fourfold pattern of risk-aversion for gains and risk-seeking for losses of

\footnotetext{
${ }^{2}$ Following Kahneman and Tversky (see Kahneman, 2003), most framing studies have employed between-subjects designs. However, it is important to note that reliable risky choice framing effects have been reported in within-subject designs where procedural precautions have been taken to avoid recognition of repeated problems by using multiple problems and presenting gain and loss versions of the same problem in separate sessions spaced widely apart (Levin et al., 2002). Emphasis in this paper will be on tasks involving actual gains and losses where separate gain and loss trials can be administered to the same decision makers without concern for consistency demands.
} 
high probability but risk-seeking for gains and risk-aversion for losses of low probability (Tversky and Kahneman, 1992). This was explained in terms of underweighting the likelihood of high probability but overweighting the likelihood of low probability events. The tasks described in this paper will primarily be of the former type. This paper describes a relatively new component of this research: neuroscientific studies that provide additional sources of data that separate risk-taking to achieve a gain and risk-taking to avoid a loss.

In presenting the most recent research in our laboratory, we focus on the "cups task" (Levin et al., 2007), which we developed specifically to separate risky decision-making for actual gains and losses, both in terms of overall riskiness and sensitivity to expected value (EV) differences between choice options. The cups task includes a gain domain and a loss domain. Gain trials involve some probability of an addition to the decision-maker's account while loss trials involve a possible reduction. Decision makers choose between one array of cups in which the outcome is constant (the riskless choice) and one array of cups in which the outcomes vary (the risky choice). Outcomes are displayed immediately after choices are made. By varying the number of cups and the amount to be won or lost, we create gain and loss trials with contingencies that either do or do not favor a risky choice (see Figure 2). For example, a one-out-of-three chance of winning five coins is better in the long run than a sure gain of one coin but a one-out-of-three chance of losing five coins is worse in the long run than a sure loss of one coin. A key component of data analysis for the cups task is the extent to which an individual makes choices based on the consideration of relative EV between choice options, for both gainand loss-related decisions. EV sensitivity represents an index of advantageous decision-making because consistently choosing the option with a more favorable EV will yield more positive outcomes in the long run. As will be described later, a somewhat simpler version of the task was adapted for use in scanner research. Across many data sets, we demonstrated that Kahneman and Tversky's (1979) original finding of more risk-taking to avoid a loss than to achieve a gain of the same magnitude is reproduced in the cups task. Beyond the initial demonstration of greater risk-taking for losses than for gains, our recent research with the cups task showed age-related differences in risk-taking as a function of decision domain (risk-taking to achieve a gain versus to avoid a loss). Risk-taking in the domain of gains decreased monotonically from early childhood to older adulthood whereas overall risk-taking to avoid losses was remarkably constant across age groups (Weller et al., 2011). Within both domains, EV sensitivity increased from early childhood through adulthood with a slight decline for older adults.

\section{EVIDENCE FROM DECISION NEUROSCIENCE}

We turn to neuroscience for an exploration of brain functions that may help explain these gain/loss behavioral differences. Our approach in this paper is to provide a body of evidence that is consistent with the proposition that risky decision-making is separable in the gain and loss domains rather than providing a single "critical" test.

Historically, the most fundamental functional division of the brain was thought to be the one that distinguished between approach and avoidance behaviors. However, many years of animal research failed to identify anatomically separate neural substratesneural systems underlying pain and pleasure seem to overlap considerably (e.g., Craig, 2009). Later human behavioral studies found equivocal support for a separation of neural systems whereby the left hemisphere is predominantly concerned with approach behaviors and the lure of reward, whereas the right hemisphere is critical for avoidance behaviors and the fear of uncertainty (Davidson et al., 1990). More recently, neuropsychological

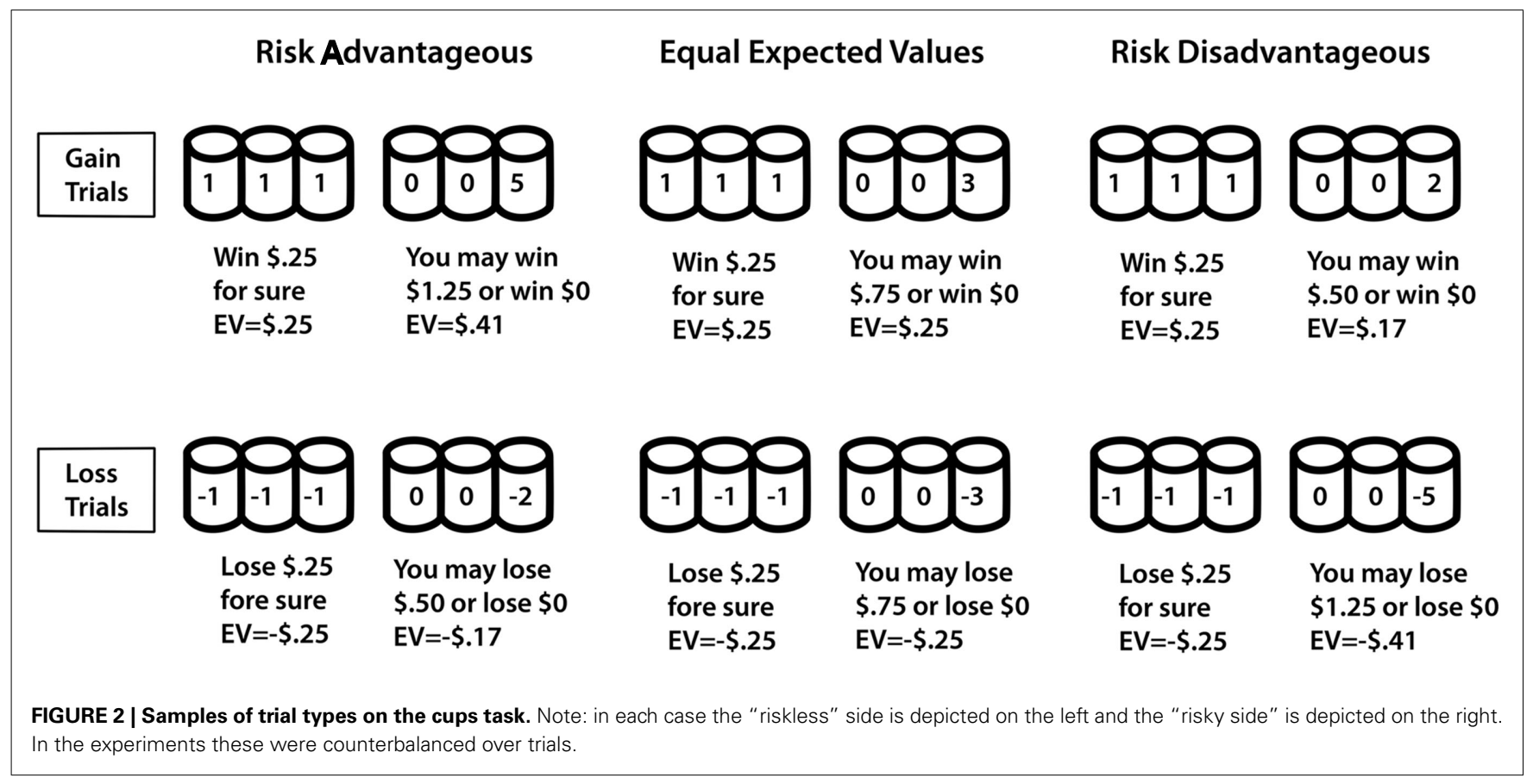


research on the approach-avoidance conflict evolved into studies of risky decision-making where the shift was to a more microscopic analysis of neural systems.

Neuroimaging data have been used to gain new insights concerning risky decision-making. In particular, fMRI studies use changes in blood flow that accompany neural activity in different parts of the brain to associate these areas to particular behaviors. For instance, in a recent meta-analysis of fMRI studies of risky decision-making using young, healthy adults, Mohr et al. (2010) found evidence common to all studies that risk processing is associated with activation of specific emotional systems in the brain such as the anterior insula, especially when potential losses are involved. The dorsolateral prefrontal cortex and parietal cortex are also activated when making decisions involving risk. Using fMRI in conjunction with a paradigm in which individuals decided whether to accept or reject gambles offering a $50 / 50$ chance of gaining or losing varying amounts of money, Tom et al. (2007) found that activity in the ventral striatum and the VMPFC increased as potential gains increased but decreased as potential losses increased. Also, in the anterior insula, activity was found more strongly associated with the anticipation of losses than with anticipation of gains (Knutson et al., 2007). Earlier research showed increased arousal following losses than following gains (Bechara et al., 1999). Such results motivated us to classify study results based on whether activation was measured before, during, or after a decision was made.

In order to get a more complete picture, we conducted a focused literature search. Using the keywords "fMRI," "gains," "losses," "risk," and "uncertainty," Table 1 summarizes the results of a number of fMRI studies in terms of which areas of the brain were studied and at what point in time, and whether the study provided support for distinct mechanisms involved in risky decisionmaking for gains and losses. While the results are "mixed," a pattern emerges when the studies are separated based on whether brain activation was measured before, during, or after a risky choice was made. Most noteworthy, while different regions were the focus of different studies, in 14 studies in which activation was assessed prior to a choice (i.e., anticipation), support for separate mechanisms was found in eight studies, four studies did not support separate structures, and two studies did not make claims about separate structures because they focused on a specific region only. For example, studies by Kuhnen and Knutson (2005) and Knutson et al. (2008b) each found that the nucleus accumbens was activated in anticipation of a risky gain, whereas the insula was activated in anticipation of a risky loss. We think these results are particularly compelling because they suggest that different parts of the brain drive risky decision-making in anticipation of uncertain gains versus uncertain losses. Whereas activation during or after a risky choice can influence subsequent risky choices, activation prior to a choice is unique in its potential to influence the current choice.

Beside the dissociation at the pre-decision stage, recent evidence suggests that experienced gains and losses might also activate different regions, which then affect subsequent decisions making. In a recent study using the cups task, we found that at the feedback stage, experienced reward was associated with strong activation in the VMPFC and the ventral striatum, and the stronger reward-related responses in the VMPFC were positively associated with risk-taking (Xue et al., 2009). In a follow up study, we explicitly examined how neural and behavioral responses to gains and losses were associated with subsequent decisions. We developed a modified version of the cups task in which a single array of cups was presented on a given trial where one coin would be lost for all but one randomly selected cup, but multiple coins would be won if the other cup was drawn (Xue et al., 2011). The decision-maker indicated whether to take or not take the gamble. In one analysis, we focused on how an experienced gain versus an experienced loss could modulate subsequent risky decision-making, both behaviorally and neurally. We found that subjects took more risk after losing a gamble than after winning a gamble. At the neural level, we again found that at the feedback stage, win was associated with stronger activation than loss in the anterior cingulate cortex, the posterior cingulate cortex, the ventral striatum, and the insula. More importantly, decisions after loss were associated with stronger activation in the frontoparietal network, which was positively correlated with individuals' increased tendency to take more risk. These results thus suggest that experienced gains and losses not only involve different brain regions, but also trigger differential neural responses and behaviors in subsequent decisions.

Despite this suggested anatomical separation, the fact remains that the same structure, for example, the insula, has sometimes been implicated in the processing of both painful and pleasurable stimuli (e.g., Craig, 2009). Indeed, when compared to a baseline of activation following trials on which the decision-maker decided not to take the gamble, both experienced gains and losses elicited strong insular activation, which then modulated subsequent decision-making (Xue et al., 2010). This calls for caution when making absolute determination about the anatomical separation of these pleasure (gain)-loss (pain) systems. In particular, a proper baseline should be included in this analysis since the same regions might show opposite modulation by gains and losses (Tom et al., 2007). Thus, the stronger activation for gains or losses in some regions might not necessarily reflect distinct neural structures for gains and losses. Another reason for these difficulties in establishing absolute anatomical separations is that cellular physiological evidence of neurons responding to positive versus negative valence stimuli, at least within the amygdala, indicates separation, while anatomical evidence is highly inter-mixed (e.g., Paton et al., 2006). This explains why the neural systems for risky gains versus losses can be functionally separate, but finding clear-cut separation viewed at the global anatomical level is more difficult, given the proximity and overlap of these two systems.

Next, we turn to lesion studies which are smaller in number in terms of addressing this issue but which should align with the "anticipatory" fMRI studies because, of course, pre-existing brain damage would likewise serve to influence revealed choices. While neuroimaging studies argue whether a particular brain region is involved in a particular function, lesion studies test whether that brain region is necessary for that function, and thus form more direct tests of the model in Figure 1 and our earlier reference to anatomically separate neural substrates. The logic here is that if a particular function is impaired in individuals with a localized lesion, then the affected neural region must play a crucial role in executing that function. Lesion studies seem to reveal little 
Table 1 | Functional magnetic resonance imaging studies of risk-taking for gains and losses.

\begin{tabular}{|c|c|c|c|c|c|c|}
\hline $\begin{array}{l}\text { Authors and } \\
\text { year }\end{array}$ & Focal topic & $\begin{array}{l}\text { Time of } \\
\text { measurement }\end{array}$ & Conditions & $\begin{array}{l}\text { Active regions } \\
\text { identified }\end{array}$ & $\begin{array}{l}\text { Sample } \\
\text { size }\end{array}$ & Result \\
\hline \multicolumn{7}{|c|}{ TIME OF MEASUREMENT BEFORE DECISION-MAKING } \\
\hline $\begin{array}{l}\text { Kuhnen and } \\
\text { Knutson } \\
\text { (2005) }\end{array}$ & $\begin{array}{l}\text { Risky decision- } \\
\text { making in a } \\
\text { financial } \\
\text { context }\end{array}$ & $\begin{array}{l}\text { Before } \\
\text { decision-making } \\
\text { (anticipation of } \\
\text { choice phase) }\end{array}$ & $\begin{array}{l}\text { Gains (risky choices } \\
\text { and risk-seeking } \\
\text { mistakes) } \\
\text { Losses (riskless } \\
\text { choices and risk- } \\
\text { aversion mistakes) } \\
\text { Gains versus losses }\end{array}$ & $\begin{array}{l}\text { Nucleus accumbens } \\
\text { Insula } \\
\text { Medial prefrontal cortex } \\
\text { Orbitofrontal cortex } \\
\text { Nucleus accumbens } \\
\text { Anterior cingulate cortex } \\
\text { Precuneus } \\
\text { Posterior cingulate }\end{array}$ & 19 & $\begin{array}{l}\text { Study supports separate } \\
\text { structures because differ- } \\
\text { ent regions were activated } \\
\text { for gains versus losses }\end{array}$ \\
\hline $\begin{array}{l}\text { Yacubian } \\
\text { et al. (2006) }\end{array}$ & $\begin{array}{l}\text { Decision- } \\
\text { making under } \\
\text { uncertainty }\end{array}$ & $\begin{array}{l}\text { Before } \\
\text { decision-making } \\
\text { (anticipation of } \\
\text { choice phase) }\end{array}$ & $\begin{array}{l}\text { Gains (computation } \\
\text { of expected value for } \\
\text { gains) } \\
\text { Losses (computation } \\
\text { of expected value for } \\
\text { losses) }\end{array}$ & $\begin{array}{l}\text { Ventral striatum } \\
\text { Amygdala }\end{array}$ & 66 & $\begin{array}{l}\text { Study supports separate } \\
\text { structures because differ- } \\
\text { ent regions were activated } \\
\text { for gains versus losses }\end{array}$ \\
\hline $\begin{array}{l}\text { Knutson } \\
\text { et al. (2007) }\end{array}$ & $\begin{array}{l}\text { Decision- } \\
\text { making in } \\
\text { purchasing } \\
\text { context }\end{array}$ & $\begin{array}{l}\text { Before } \\
\text { decision-making } \\
\text { (anticipation of } \\
\text { choice phase) }\end{array}$ & $\begin{array}{l}\text { Losses (spending } \\
\text { money) }\end{array}$ & $\begin{array}{l}\text { Anterior cingulate cortex } \\
\text { Dorsolateral prefrontal cortex } \\
\text { Medial frontal gyrus } \\
\text { Superior frontal gyrus } \\
\text { Anterior insula } \\
\text { Nucleus accumbens } \\
\text { Caudate } \\
\text { Globus pallidus } \\
\text { Posterior cingulate } \\
\text { Frontopolar cortex } \\
\text { Medial prefrontal cortex } \\
\text { Anterior cingulate cortex } \\
\text { Parahippocampal gyrus }\end{array}$ & 26 & $\begin{array}{l}\text { Study supports separate } \\
\text { structures because differ- } \\
\text { ent regions were activated } \\
\text { for gains versus losses }\end{array}$ \\
\hline
\end{tabular}


Table 1 | Continued

\begin{tabular}{|c|c|c|c|c|c|c|}
\hline $\begin{array}{l}\text { Authors and } \\
\text { year }\end{array}$ & Focal topic & $\begin{array}{l}\text { Time of } \\
\text { measurement }\end{array}$ & Conditions & $\begin{array}{l}\text { Active regions } \\
\text { identified }\end{array}$ & $\begin{array}{l}\text { Sample } \\
\text { size }\end{array}$ & Result \\
\hline $\begin{array}{l}\text { Seymour } \\
\text { et al. (2007) }\end{array}$ & $\begin{array}{l}\text { Risky decision- } \\
\text { making in a } \\
\text { financial } \\
\text { context }\end{array}$ & $\begin{array}{l}\text { Before } \\
\text { decision-making } \\
\text { (prediction error } \\
\text { phase) }\end{array}$ & $\begin{array}{l}\text { Gains (rewards) } \\
\text { Losses }\end{array}$ & $\begin{array}{l}\text { Anterior striatum } \\
\text { Posterior striatum }\end{array}$ & 20 & $\begin{array}{l}\text { Study supports separate } \\
\text { structures because differ- } \\
\text { ent regions were activated } \\
\text { for gains versus losses }\end{array}$ \\
\hline $\begin{array}{l}\text { Knutson } \\
\text { et al. } \\
\text { (2008a) }\end{array}$ & $\begin{array}{l}\text { Decision- } \\
\text { making in a } \\
\text { buying and } \\
\text { selling context }\end{array}$ & $\begin{array}{l}\text { Before } \\
\text { decision-making } \\
\text { (anticipation of } \\
\text { choice phase) }\end{array}$ & $\begin{array}{l}\text { Gains (buying versus } \\
\text { selling at low prices) } \\
\text { Buying and selling of } \\
\text { preferred products } \\
\text { Losses (selling } \\
\text { product) }\end{array}$ & $\begin{array}{l}\text { Medial prefrontal cortex } \\
\text { Nucleus accumbens } \\
\text { Insula }\end{array}$ & 24 & $\begin{array}{l}\text { Study supports separate } \\
\text { structures because differ- } \\
\text { ent regions were activated } \\
\text { for gains versus losses }\end{array}$ \\
\hline $\begin{array}{l}\text { Knutson } \\
\text { et al. } \\
\text { (2008b) }\end{array}$ & $\begin{array}{l}\text { Risky decision- } \\
\text { making in a } \\
\text { financial } \\
\text { context }\end{array}$ & $\begin{array}{l}\text { Before } \\
\text { decision-making } \\
\text { (anticipation of } \\
\text { choice phase) }\end{array}$ & $\begin{array}{l}\text { Gains (high-risk shift } \\
\text { versus low-risk shift) } \\
\text { Gains versus losses }\end{array}$ & $\begin{array}{l}\text { Anterior insula } \\
\text { Caudate } \\
\text { Nucleus accumbens } \\
\text { Medial prefrontal cortex } \\
\text { Caudate } \\
\text { Putamen } \\
\text { Inferior frontal gyrus } \\
\text { Precentral gyrus } \\
\text { Posterior cingulate } \\
\text { Lingual gyrus }\end{array}$ & 15 & $\begin{array}{l}\text { Study supports separate } \\
\text { structures because differ- } \\
\text { ent regions were activated } \\
\text { for gains versus losses }\end{array}$ \\
\hline $\begin{array}{l}\text { Breiter } \\
\text { et al. (2001) }\end{array}$ & $\begin{array}{l}\text { Expectancy } \\
\text { and } \\
\text { experience of } \\
\text { monetary } \\
\text { gains and } \\
\text { losses }\end{array}$ & $\begin{array}{l}\text { Before } \\
\text { decision-making } \\
\text { (expectancy } \\
\text { phase) }\end{array}$ & Losses (bad spinner) & $\begin{array}{l}\text { Frontal lobe } \\
\text { Amygdala } \\
\text { Nucleus accumbens } \\
\text { Sublenticular extended } \\
\text { amygdala } \\
\text { Hypothalamus } \\
\text { Frontal lobe } \\
\text { Amygdala } \\
\text { Nucleus accumbens } \\
\text { Sublenticular extended } \\
\text { amygdala }\end{array}$ & 12 & $\begin{array}{l}\text { Study does not sup- } \\
\text { port separate structures } \\
\text { because same key regions } \\
\text { were activated for both } \\
\text { gains and losses }\end{array}$ \\
\hline $\begin{array}{l}\text { Paulus and } \\
\text { Frank } \\
\text { (2006) }\end{array}$ & $\begin{array}{l}\text { Comparison of } \\
\text { high versus } \\
\text { low probability } \\
\text { prospects }\end{array}$ & $\begin{array}{l}\text { Before } \\
\text { decision-making } \\
\text { (from onset of the } \\
\text { presentation of } \\
\text { the options until } \\
\text { the subject had } \\
\text { made a response) }\end{array}$ & $\begin{array}{l}\text { Losses (high } \\
\text { probability } \\
\text { prospects) versus } \\
\text { gains (low probability } \\
\text { prospects) }\end{array}$ & $\begin{array}{l}\text { Precuneus } \\
\text { Cingulate gyrus } \\
\text { Insula } \\
\text { Middle frontal gyrus } \\
\text { Middle occipital gyrus } \\
\text { Precuneus } \\
\text { Superior parietal lobule } \\
\text { Insula } \\
\text { Thalamus } \\
\text { Postcentral gyrus } \\
\text { Inferior parietal lobule } \\
\text { Middle frontal gyrus } \\
\text { Superior temporal gyrus } \\
\text { Precentral gyrus } \\
\text { Caudate }\end{array}$ & 16 & $\begin{array}{l}\text { Study does not sup- } \\
\text { port separate structures } \\
\text { because same regions } \\
\text { were activated for both } \\
\text { gains and losses }\end{array}$ \\
\hline
\end{tabular}


Table 1 | Continued

\begin{tabular}{|c|c|c|c|c|c|c|}
\hline $\begin{array}{l}\text { Authors and } \\
\text { year }\end{array}$ & Focal topic & $\begin{array}{l}\text { Time of } \\
\text { measurement }\end{array}$ & Conditions & $\begin{array}{l}\text { Active regions } \\
\text { identified }\end{array}$ & $\begin{array}{l}\text { Sample } \\
\text { size }\end{array}$ & Result \\
\hline $\begin{array}{l}\text { Tom et al. } \\
\text { (2007) }\end{array}$ & $\begin{array}{l}\text { Risky decision- } \\
\text { making and } \\
\text { loss aversion }\end{array}$ & $\begin{array}{l}\text { Before } \\
\text { decision-making } \\
\text { (anticipation of } \\
\text { potential gains or } \\
\text { losses phase) }\end{array}$ & $\begin{array}{l}\text { Gains (potential gain } \\
\text { effects) }\end{array}$ & $\begin{array}{l}\text { Nucleus accumbens } \\
\text { Caudate } \\
\text { Thalamus } \\
\text { Ventromedial prefrontal cortex } \\
\text { Orbitofrontal cortex } \\
\text { Frontal pole } \\
\text { Middle frontal gyrus } \\
\text { Middle/superior frontal gyrus } \\
\text { Posterior cingulate } \\
\text { Midbrain } \\
\text { Nucleus accumbens } \\
\text { Caudate } \\
\text { Thalamus } \\
\text { Ventromedial prefrontal cortex } \\
\text { Orbitofrontal cortex } \\
\text { Frontal pole } \\
\text { Middle frontal gyrus } \\
\text { Middle/superior frontal gyrus } \\
\text { Posterior cingulate } \\
\text { Midbrain }\end{array}$ & 16 & $\begin{array}{l}\text { Study does not sup- } \\
\text { port separate structures } \\
\text { because same regions } \\
\text { were activated for both } \\
\text { gains and losses }\end{array}$ \\
\hline $\begin{array}{l}\text { Preuschoff } \\
\text { et al. (2008) }\end{array}$ & $\begin{array}{l}\text { Risk prediction } \\
\text { error and risk } \\
\text { in decision- } \\
\text { making }\end{array}$ & $\begin{array}{l}\text { Before } \\
\text { decision-making } \\
\text { (prediction phase) }\end{array}$ & Risk prediction error & Insula & 19 & $\begin{array}{l}\text { Study does not make } \\
\text { claims about separate } \\
\text { structures because the } \\
\text { insula was the region of } \\
\text { focus }\end{array}$ \\
\hline $\begin{array}{l}\text { Tobler et al. } \\
\text { (2009) }\end{array}$ & $\begin{array}{l}\text { Risk and } \\
\text { expected value } \\
\text { in decision- } \\
\text { making }\end{array}$ & $\begin{array}{l}\text { Before } \\
\text { decision-making } \\
\text { (prediction phase) }\end{array}$ & $\begin{array}{l}\text { Gains (increased } \\
\text { risk-seeking) } \\
\text { Losses (increase } \\
\text { risk-aversion) }\end{array}$ & $\begin{array}{l}\text { Lateral prefrontal cortex } \\
\text { Lateral prefrontal cortex }\end{array}$ & 15 & $\begin{array}{l}\text { Study does not sup- } \\
\text { port separate structures } \\
\text { because same regions } \\
\text { were activated for both } \\
\text { gains and losses }\end{array}$ \\
\hline $\begin{array}{l}\text { Gottfried } \\
\text { et al. (2002) }\end{array}$ & $\begin{array}{l}\text { Appetitive and } \\
\text { aversive } \\
\text { olfactory } \\
\text { learning }\end{array}$ & $\begin{array}{l}\text { During learning } \\
\text { phase }\end{array}$ & $\begin{array}{l}\text { Gains (appetitive } \\
\text { olfactory learning) }\end{array}$ & $\begin{array}{l}\text { Medial orbitofrontal cortex } \\
\text { Anterior orbitofrontal cortex } \\
\text { Ventral striatum } \\
\text { Nucleus accumbens } \\
\text { Pallidum/dorsomedial } \\
\text { amygdala } \\
\text { Uncus/ventromedial amygdala } \\
\text { Dorsomedial amygdala } \\
\text { Ventromedial prefrontal cortex } \\
\text { Cerebellar hemisphere } \\
\text { Anterior hippocampus }\end{array}$ & 15 & $\begin{array}{l}\text { Study does not sup- } \\
\text { port separate structures } \\
\text { because same key regions } \\
\text { were activated for both } \\
\text { gains and losses }\end{array}$ \\
\hline
\end{tabular}


Table 1 | Continued

\begin{tabular}{|c|c|c|c|c|c|c|}
\hline $\begin{array}{l}\text { Authors and } \\
\text { year }\end{array}$ & Focal topic & $\begin{array}{l}\text { Time of } \\
\text { measurement }\end{array}$ & Conditions & $\begin{array}{l}\text { Active regions } \\
\text { identified }\end{array}$ & $\begin{array}{l}\text { Sample } \\
\text { size }\end{array}$ & Result \\
\hline $\begin{array}{l}\text { Paulus et al. } \\
\text { (2003) }\end{array}$ & $\begin{array}{l}\text { Risky decision- } \\
\text { making }\end{array}$ & $\begin{array}{l}\text { During } \\
\text { decision-making }\end{array}$ & $\begin{array}{l}\text { Gains (risky } \\
\text { response versus } \\
\text { safe response) } \\
\text { Losses (risky } \\
\text { response versus } \\
\text { punishment } \\
\text { eesnonse) }\end{array}$ & $\begin{array}{l}\text { Lateral orbitofrontal cortex } \\
\text { Medial orbitofrontal cortex } \\
\text { Nucleus accumbens } \\
\text { Temporal pole/piriform cortex } \\
\text { Insula } \\
\text { Cuneus } \\
\text { Precuneus } \\
\text { Middle frontal gyrus } \\
\text { Inferior frontal gyrus } \\
\text { Insula } \\
\text { Superior parietal lobule }\end{array}$ & 17 & $\begin{array}{l}\text { Study does not clearly sup- } \\
\text { port separate structures } \\
\text { because same key region } \\
\text { (here: insula) was activated } \\
\text { for both gains and losses } \\
\text { but to a greater extent for } \\
\text { risky versus safe responses }\end{array}$ \\
\hline $\begin{array}{l}\text { Plassmann } \\
\text { et al. (2010) }\end{array}$ & $\begin{array}{l}\text { Processing of } \\
\text { appetitive } \\
\text { versus } \\
\text { aversive goal } \\
\text { values }\end{array}$ & $\begin{array}{l}\text { During } \\
\text { decision-making } \\
\text { (decision-making } \\
\text { phase) }\end{array}$ & $\begin{array}{l}\text { Gains (appetitive } \\
\text { goal values) } \\
\text { Losses (aversive } \\
\text { goal values) }\end{array}$ & $\begin{array}{l}\text { Medial orbitofrontal cortex } \\
\text { Dorsolateral prefrontal cortex } \\
\text { Medial orbitofrontal cortex } \\
\text { Dorsolateral prefrontal cortex }\end{array}$ & 19 & $\begin{array}{l}\text { Study does not sup- } \\
\text { port separate structures } \\
\text { because same key regions } \\
\text { were activated for both } \\
\text { gains and losses }\end{array}$ \\
\hline \multicolumn{7}{|c|}{ TIME OF MEASUREMENT AFTER DECISION-MAKING (OUTCOME PROCESSING) } \\
\hline $\begin{array}{l}\text { Hsu et al. } \\
(2005)\end{array}$ & $\begin{array}{l}\text { Ambiguous } \\
\text { decision- } \\
\text { making }\end{array}$ & $\begin{array}{l}\text { After } \\
\text { decision-making } \\
\text { (response to risk) }\end{array}$ & $\begin{array}{l}\text { Losses (certainty } \\
\text { versus gamble) }\end{array}$ & $\begin{array}{l}\text { Occipital cortex } \\
\text { Medial frontal gyrus } \\
\text { Brodmann area } 6 \\
\text { Precentral gyrus } \\
\text { Insula } \\
\text { Caudate head } \\
\text { Brodmann area } 18 \\
\text { Insula } \\
\text { Middle temporal gyrus } \\
\text { Precentral gyrus } \\
\text { Occipital cortex }\end{array}$ & 16 & $\begin{array}{l}\text { Study supports separate } \\
\text { structures because addi- } \\
\text { tional other regions were } \\
\text { activated for gains com- } \\
\text { pared to losses }\end{array}$ \\
\hline \multirow[t]{3}{*}{$\begin{array}{l}\text { Fujiwara } \\
\text { et al. (2009) }\end{array}$} & $\begin{array}{l}\text { Monetary } \\
\text { reward and } \\
\text { punishment }\end{array}$ & $\begin{array}{l}\text { After } \\
\text { decision-making } \\
\text { (presentation of } \\
\text { chosen outcome) }\end{array}$ & Gain-specific regions & $\begin{array}{l}\text { Anterior cingulate cortex } \\
\text { Posterior cingulate cortex } \\
\text { Superior frontal gyrus } \\
\text { Inferior operculum } \\
\text { Insula } \\
\text { Midbrain } \\
\text { Inferior temporal gyrus } \\
\text { Inferior parietal lobule } \\
\text { Cerebellum }\end{array}$ & 17 & $\begin{array}{l}\text { Study does not sup- } \\
\text { port separate structures } \\
\text { because same key regions } \\
\text { were activated for both } \\
\text { gains and losses }\end{array}$ \\
\hline & & & Loss-specific regions & $\begin{array}{l}\text { Anterior cingulate cortex } \\
\text { Inferior operculum } \\
\text { Insula }\end{array}$ & & \\
\hline & & & $\begin{array}{l}\text { Common gain and } \\
\text { loss regions }\end{array}$ & $\begin{array}{l}\text { Anterior cingulate cortex } \\
\text { Posterior cingulate cortex } \\
\text { Postcentral gyrus }\end{array}$ & & \\
\hline
\end{tabular}


Table 1 | Continued

\begin{tabular}{|c|c|c|c|c|c|c|}
\hline $\begin{array}{l}\text { Authors and } \\
\text { year }\end{array}$ & Focal topic & $\begin{array}{l}\text { Time of } \\
\text { measurement }\end{array}$ & Conditions & $\begin{array}{l}\text { Active regions } \\
\text { identified }\end{array}$ & $\begin{array}{l}\text { Sample } \\
\text { size }\end{array}$ & Result \\
\hline & & & & Inferior operculum & & \\
\hline & & & & Insula & & \\
\hline & & & & Midbrain & & \\
\hline & & & & Middle temporal gyrus & & \\
\hline
\end{tabular}

This table is sorted by time of measurement (before, during, or after decision-making) and by result (supportive of separate structures or not). In each category, the table is sorted first in chronological order, then in alphabetical order.

dissociation between the domains of gains and losses within the prefrontal cortex region, but such dissociations are more likely to be revealed when one considers two other neural systems, the insula and amygdala, which feed information into the prefrontal cortex. Indeed, within the prefrontal cortex, patients with damage to the VMPFC show deficits for both risky gains and risky losses (Weller et al., 2007). Compared to healthy controls, VMPFC patients showed increased levels of risk-taking and decreased sensitivity to EV differences in both gain and loss domains. In contrast, amygdala patients showed impaired decision-making and exaggerated levels of risk-taking to achieve gains. However, in the loss domain amygdala damage was not associated with significantly increased risk-taking or decreased EV sensitivity. Given the abundance of literature suggesting that the amygdala is involved with avoidance of punishment, this finding suggests that other structures may act in concert with the amygdala to produce a signal that engages the VMPFC. When patients with insula damage were compared to controls, a different pattern emerged (Weller et al., 2009). Consistent with research suggesting that the insula is important for risk processing (Preuschoff et al., 2008), insula lesion patients like VMPFC and amygdala patients showed decreased sensitivity to EV differences between choice options for both risky gains and risky losses. However, these individuals showed lower levels of risk-taking compared to healthy controls, especially on gain trials. Thus the insula, with connections to the amygdala, ventral striatum, and the VMPFC, may serve the purpose of providing a "gate" to determine the effectiveness of excitatory and inhibitory motivational circuits, signaling approach or danger. Subsequently, insula damage may result in a blunted response toward risk, and would lead to insensitivity to changes in environmental contingencies signaling the approach or avoidance of a risk, regardless of domain.

Because the amygdala and insula have long been implicated in the processing of negative emotions, evoked from stimuli that are particularly aversive and perhaps even a threat to survival (e.g., LeDoux, 2000; Paulus and Stein, 2006; Phelps, 2006), we argue that these emotional reactions may be processed by multiple neural structures and are thus more difficult to disrupt as a result of a focal lesion to the amygdala or the insula alone $e^{3}$. Specifically, a person with a damaged amygdala but an intact insula can still

\footnotetext{
${ }^{3}$ It should be noted that redundancy has also been found in learning and memory systems, which allow learning to occur in multiple parallel memory systems; see Pinker and Ullman (2002) for an example of how multiple memory systems support the generation of verb past-tense.
}

make reasoned decisions in the domain of losses even when they cannot in the domain of gains. While a separation in processing gains and losses is achieved at the level of the amygdala versus insular cortex, the two neural systems may come closely together (and become more difficult to dissociate) by the time information reaches the prefrontal cortex, which responds similarly to risky gains and risky losses. Nevertheless, when considering the evidence from both insula and amygdala lesions, support for separate processes for risky decision-making in the gain and loss domains seems to emerge. Consistent with our model, the insula, in addition to its general role in processing risk, serves to especially aid in recruitment of the VMPFC to guide risky decisions in the more emotion-laden loss domain.

\section{SUMMARY AND CONCLUSION}

Taken individually, each of the neuroimaging and lesion studies reviewed here has its limitations. Lesion studies are limited to the small sample of available participants who meet the criteria of damage to a targeted area. Furthermore, some of those included may have collateral damage to other adjacent areas. fMRI studies also typically have small sample size due to financial and time constraints. Furthermore, the complexity and length of tasks that can be conducted in a scanner are limited. Also, because different studies focus on different areas (see Table 1), comparisons, and integration of findings can be difficult. Finally, for present purposes, the tasks used in the different studies differed in their ability to separate the gain and loss domains.

Nevertheless, we believe that we can provide a meaningful summary of the findings reviewed here. Behavioral studies suggest differences in decision-making for risky gains and risky losses. A study comparing different age groups suggests different developmental trajectories for risk-taking in the gain and loss domains. Neuroimaging studies are sometimes inconclusive in mapping brain systems to differential reactions to risky gains and losses. For example, while there is evidence that a system such as the VMPFC or the striatum is involved in both risky gains and losses, different parts of the system may be differentially sensitive to gains and losses (Xue et al., 2009). In such cases, the more general hypothesis of separate processes underlying risk-taking for gains and losses is still supported. With regard to the stricter hypothesis of separate structures, a breakdown of fMRI studies in Table 1 shows the strongest evidence for this hypothesis when recordings capture pre-decisional or anticipatory processes. We believe that the lesion studies provide the most direct evidence implicating separate structures. 
Although a more detailed meta-analysis is clearly warranted, Table 1 shows that a wide variety of structures are involved in risky decision-making beyond those depicted in Figure 1. Nevertheless, we feel that the relatively simple depiction of the model represents a good start in capturing the different neurological underpinnings of risk-taking for gains and losses. The complementary roles of the VMPFC, amygdala, and insula depicted in the model are consistent with both the general hypothesis that

\section{REFERENCES}

Bechara, A., and Damasio, A. R. (2005). The somatic marker hypothesis: a neural theory of economic decision. Games Econ. Behav. 52, 336-372.

Bechara, A., Damasio, A. R., Damasio, H., and Anderson, S. W. (1994). Insensitivity to future consequences following damage to human prefrontal cortex. Cognition 50, 7-15.

Bechara, A., Damasio, H., Damasio, A. R., and Lee, G. P. (1999). Different contributions of the amygdala and ventromedial prefrontal cortex to decision-making. J. Neurosci. 19, 5473-5481.

Bechara, A., Damasio, H., Tranel, D., and Damasio, A. R. (1997). Deciding advantageously before knowing the advantageous strategy. Science 275, 1293-1295.

Bechara, A., Tranel, D., Damasio, H., and Damasio, A. R. (1996). Failure to respond autonomically to anticipated future outcomes following damage to prefrontal cortex. Cereb. Cortex 6, 215-225.

Breiter, H. C., Aharon, I., Kahneman, D., Dale, A., and Shizgal, P. (2001). Functional imaging of neural responses to expectancy and experience of monetary gains and losses. Neuron 30, 619-639.

Clark, L., Bechara, A., Damasio, H., Aitken, M. R. F., Sahakian, B. J., and Robbins, T. W. (2008). Distinct patterns of risky decision-making in patients with lesions to ventromedial prefrontal cortex and insular cortex. Brain 131, 1311-1322.

Craig, A. D. (2009). How do you feel now? The anterior insula and human awareness. Nat. Rev. Neurosci. 10, 59-70.

Damasio, A. R. (1994). Descartes' Error: Emotion, Reason, and the Human Brain. New York, NY: Putnam.

Davidson, R., Ekman, P., Saron, C., Senulis, J., and Friesen, W. (1990). Approach-withdrawal and cerebral asymmetry: emotional expression and brain physiology I. J. Pers. Soc. Psychol. 58, 330-341.

De Martino, B., Kumaran, D., Seymour, B., and Dolan, R. J. (2006). Frames, biases, and rational decision-making in the human brain. Science 313, 684-687.
Fujiwara, J., Tobler, P. N., Taira, M., Iijima, T., and Tsutsui, K. I. (2009). Segregated and integrated coding of reward and punishment in the cingulate cortex. J. Neurophysiol. 101, 3284 .

Fukui, H., Murai, T., Fukuyama, H., Hayashi, T., and Hanakawa, T. (2005). Functional activity related to risk anticipation during perforNeuroimage 24, 253-259.

Gottfried, J. A., O’Doherty, J., and Dolan, R. J. (2002). Appetitive and aversive olfactory learning in humans studied using eventrelated functional magnetic resonance imaging. J. Neurosci. 22, 10829-10837.

Hsu, M., Bhatt, M., Adolphs, R., Tranel, D., and Camerer, C. F. (2005). Neural systems responding to degrees of uncertainty in human decisionmaking. Science 310, 1680.

Huettel, S. A., Song, A. W., and McCarthy, G. (2005). Decisions under uncertainty: probabilistic context influences activation of prefrontal and parietal cortices. J. Neurosci. 25, 3304-3311.

Huettel, S. A., Stowe, C. J., Gordon, E. M., Warner, B. T., and Platt, M. L. (2006). Neural signatures of economic preferences for risk and ambiguity. Neuron 49, 776-775.

Kahneman, D. (2003). Perspective on judgment and choice: mapping bounded rationality. Am. Psychol. 58, 697-720.

Kahneman, D., and Tversky, A. (1979). Prospect theory - analysis of decision under risk. Econometrica 47, 263-291.

Knutson, B., Adams, C. M., Fong, G. W., and Hommer, D. (2001). Anticipation of increasing monetary reward selectively recruits nucleus accumbens. J. Neurosci. 21, 159-164.

Knutson, B., Rick, S., Wimmer, G. E., Prelec, D., and Loewenstein, G. (2007). Neural predictors of purchases. Neuron 53, 147-156.

Knutson, B., Wimmer, G. E., Kuhnen, C. M., and Winkielman, P. (2008a). Nucleus accumbens actimance of the Iowa gambling task. vation mediates the influence of

separate processes underlie risk-taking for gains and losses, and the stricter hypothesis of separate neural structures coming together in different ways to guide risky decision-making in the gain and loss domains. In conclusion, we find that evidence of different neural responses underlying risk-taking for gains and losses favors the hypothesis that decision makers react differently to risky gains and losses, both in terms of overt risk-taking and neural activation.

reward cues on financial risk taking. Neuroreport 19, 509-513.

Knutson, B., Wimmer, G. E., Rick, S., Hollon, N. G., Prelec, D., and Loewenstein, G. (2008b). Neural antecedents of the endowment effect. Neuron 58, 814-822.

Kuhnen, C. M., and Knutson, B. (2005) The neural basis of financial risk taking. Neuron 47, 763-770.

LeDoux, J. E. (2000). Emotion circuits in the brain. Annu. Rev. Neurosci. 2, 155-184.

Levin, I. P., Gaeth, G. J., Schreiber, J., and Lauriola, M. (2002). A new look at framing effects: Distribution of effect sizes, individual differences, and independence of types of effects. Organ. Behav. Hum. Decis. Process. 88, 411-429.

Levin, I. P., Weller, J. A., Pederson, A. and Harshman, L. A. (2007). Agerelated differences in adaptive decision making: sensitivity to expected value in risky choice. Judgm. Decis. Mak. 2 225-233.

Loewenstein, G. F., Weber, E. U. Hsee, C. K., and Welch, N. (2001). Risk as feelings. Psychol. Bull. 127, 267-286.

Matthews, S. C., Simmons, A. N., Lane, S. D., and Paulus, M. P. (2004). Selective activation of the nucleus accumbens during risk-taking decision making. Neuroreport 15, 2123-2127.

Mellers, B. A., Schwartz, A., and Ritov, I. (1999). Emotion-based choice. J. Exp. Psychol. 128, 1-14.

Mohr, P. N. C., Biele, G., and Heekeren, H. R. (2010). Neural processing of risk. J. Neurosci. 30, 6613-6619.

O’Doherty, J. P., Kringelbach, M. L. Rolls, E. T., Hornak, J., and Andrews, C. (2001). Abstract reward and punishment representations in the human orbitofrontal cortex. Nat. Neurosci. 4, 95-102.

Paton, J. J., Belova, M. A., Morrison, S. E., and Salzman, C. D. (2006). The primate amygdala represents the positive and negative value of visual stimuli during learning. Nature 439 , 865-870.

Paulus, M. P., and Frank, L. R. (2006) Anterior cingulate activity modulates nonlinear decision weight function of uncertain prospects. Neuroimage 30, 668-677.

Paulus, M. P., Rogalsky, C., Simmons, A., Feinstein, J. S., and Stein, M. B. (2003). Increased activation in the right insula during risk-taking decision making is related to harm avoidance and neuroticism. Neuroimage 19, 1439-1448.

Paulus, M. P., and Stein, M. B. (2006). An insular view of anxiety. Biol. Psychiatry 60, 383-387.

Phelps, E. A. (2006). Emotion and cognition: insights from studies of the human amygdala. Annu. Rev. Psychol. 57, 27-53.

Pinker, S., and Ullman, M. T. (2002) The past and future of past tense. Trends Cogn. Sci. (Regul. Ed.) 6, 456-463.

Plassmann, H., O’Doherty, J. P., and Rangel, A. (2010). Appetitive and aversive goal values are encoded in the medial orbitofrontal cortex at the time of decision making. J. Neurosci. 30, 10799.

Preuschoff, K., Quartz, S. R., and Bossaerts, P. (2008). Human insula activation reflects risk prediction errors as well as risk. J. Neurosci. 28, 2745-2752.

Reimann, M., and Bechara, A. (2010). The somatic marker framework as a neurological theory of decisionmaking: review, conceptual comparisons, and future neuroeconomic research. J. Econ. Psychol. 31, 767-776.

Sanfey, A. G., Rilling, J. K., Aronson, J. A., Nystrom, L. E., and Cohen, J. D. (2003). The neural basis of economic decision-making in the ultimatum game. Science 300 , 1755-1758.

Seymour, B., Daw, N., Dayan, P., Singer, T., and Dolan, R. (2007). Differential encoding of losses and gains in the human striatum. J. Neurosci. 27, 4826-4831.

Slovic, P., Finucane, M., Peters, E., and MacGregor, D. (2002). "The affect heuristic," in Heuristic and Biases: The Psychology of Intuitive Judgment, eds T. Gilovich, D. Griffin, and D. Kahneman (New York, NY: Cambridge University Press), 397-420. 
Tobler, P. N., Christopoulos, G. I., O'Doherty, J. P., Dolan, R. J., and Schultz, W. (2009). Risk-dependent reward value signal in human prefrontal cortex. Proc. Natl. Acad. Sci. U.S.A. 106, 7185.

Tom, S. M., Fox, C. R., Trepel, C., and Poldrack, R. A. (2007). The neural basis of loss aversion in decisionmaking under risk. Science 315, 515-518.

Trepel, C., Fox, C. R., and Poldrak, R. A. (2005). Prospect theory on the brain? Toward a cognitive neuroscience of decisions under risk. Brain Res. Cogn. Brain Res. 23, 34-50.

Tversky, A., and Kahneman, D. (1992). Advances in prospect theory: cumulative representation of uncertainty. J. Risk Uncertain 5, 297-323.

Weber, E., Blais, A., and Betz, N. (2002). A domain-specific risk-attitude scale: measuring risk perceptions and risk behaviors. J. Behav. Decis. Mak. 15, 263-290.

Weller, J. A., Levin, I. P., and Denburg, N. (2011). Trajectory of risky decision making for potential gains and losses from age 5 to 85. J. Behav. Decis. Mak. 24, 331-344.

Weller, J. A., Levin, I. P., Shiv, B., and Bechara, A. (2007). Neural correlates of adaptive decision making for risky gains and losses. Psychol. Sci. 18, 958-964.

Weller, J. A., Levin, I. P., Shiv, B., and Bechara, A. (2009). The effects of insula damage on decision-making for risky gains and losses. Soc. Neurosci. 4, 347-358.

Xue, G., Lu, Z., Levin, I. P., and Bechara, A. (2010). The impact of prior risk experiences on subsequent risky decision-making: the role of the insula. Neuroimage 50, 709-716.
Xue, G., Lu, Z., Levin, I. P., and Bechara, A. (2011). An fMRI study of risk-taking following wins and losses: implications for the gambler's fallacy. Hum. Brain Mapp. 32, 271-281.

Xue, G., Lu, Z., Levin, I. P., Weller, J. A., Li, X., and Bechara, A. (2009). Functional dissociations of risk and reward processing in the medial prefrontal cortex. Cereb. Cortex 19 1019-1027.

Yacubian, J., Gläscher, J., Schroeder, K., Sommer, T., Braus, D. F., and Büchel, C. (2006). Dissociable systems for gain-and loss-related value predictions and errors of prediction in the human brain. J. Neurosci. 26, 9530-9537.

Conflict of Interest Statement: The authors declare that the research was conducted in the absence of any commercial or financial relationships that could be construed as a potential conflict of interest.

Received: 06 July 2011; accepted: 19 January 2012; published online: 07 February 2012.

Citation: Levin IP, Xue G, Weller JA, Reimann $M$, Lauriola $M$ and Bechara A (2012) A neuropsychological approach to understanding risk-taking for potential gains and losses. Front. Neurosci. 6:15. doi: 10.3389/fnins.2012.00015

This article was submitted to Frontiers in Decision Neuroscience, a specialty of Frontiers in Neuroscience.

Copyright (c) 2012 Levin, Xue, Weller, Reimann, Lauriola and Bechara. This is an open-access article distributed under the terms of the Creative Commons Attribution Non Commercial License, which permits non-commercial use, distribution, and reproduction in other forums, provided the original authors and source are credited. 